\title{
Poland as a hub of the Silk Road Economic Belt: is the narrative of opportunity supported by developments on the ground?
}

\section{Andrzej Jakubowski ${ }^{1}$ (D) Tomasz Komornicki $^{2}$ (D) Karol Kowalczyk $^{1}$ (D) Andrzej Miszczuk ${ }^{3}$}

Received: 28 March 2019 / Revised: 27 March 2020 / Accepted: 20 April 2020 /

Published online: 14 May 2020

(C) The Author(s) 2020

\begin{abstract}
The article presents an analysis of Poland's potential role as a European hub supporting the transportation of goods on the route between China and the EU. The authors point out a number of factors that can favour the development of a Silk Road Economic Belt (SREB) hub in Poland. At the same time, they emphasise that higher demand for shipments through the New Eurasian Land Bridge within the SREB does not automatically mean that Poland will become the main hub on its European end. The study highlights several important aspects of competition as a result of which Poland is likely to adopt the role of a regional hub in Central and Eastern Europe.
\end{abstract}

Keywords Beltand Road Initiative · Silk Road Economic Belt · New Eurasian Land Bridge · Poland $\cdot$ Transport infrastructure $\cdot$ International trade

JEL Classification R40 · F14 · P45 · P48

\section{Introduction}

Since the Chinese concept of the Belt and Road Initiative (BRI) was presented in 2013, ${ }^{1}$ a global discussion has arisen concerning the undertaking's chances of success and its

${ }^{1}$ Before 2016 known as the One Belt, One Road Initiative (OBOR).

Andrzej Jakubowski

andrzej.jakubowski@umcs.pl

1 Faculty of Earth Sciences and Spatial Management, Maria Curie-Skłodowska University, Al. Kraśnicka 2d, 20-718 Lublin, Poland

2 Stanisław Leszczycki Institute of Geography and Spatial Organization, Polish Academy of Sciences, Warsaw, Poland

3 Faculty of Economics, Maria Curie-Skłodowska University, Lublin, Poland 
geopolitical and economic consequences (Kaczmarski 2017; Ye 2015). Simultaneously, many countries involved in discussions on the initiative have begun to analyse potential benefits and threats resulting from its implementation. The BRI also drew strong interest from scholars analysing the potential impact of the BRI on the global economy (Aoyama 2016; Beeson 2018; Clarke 2018; Liu et al. 2018) as well as the economic situation at the regional level (Chubarov 2018; Holslag 2017; Kamel 2018; Silin et al. 2018; Travis Selmier II 2018) and national level (Khan and Liu 2018; Salik 2018).

Poland is one of the countries in which relatively positive views of the Chinese project predominated in the early phases, but were supplemented over time with an awareness of the risks and even threats it entailed (Bartosiewicz and Szterlik 2019; Górski 2017; Grzywacz 2020; Lubina 2017; Pendrakowska 2018; Szczudlik 2016a). The initiative is often presented as a chance for economic development, with scholars pointing to the potentially key importance of Poland as a transit country located at the boundary of two geopolitical regions. In this context, the discussion sometimes leverages Polish symbolism and national myths that present the potential role of Poland as the "gateway to Europe".

The most frequently used argument for such an approach to the implementation of the BRI project is the geographic and geopolitical location of Poland on the route of the existing New Eurasian Land Bridge Economic Corridor, which runs through the territory of Kazakhstan, Russia, and Belarus. From a logistical point of view, its location at the confluence of two systems of railway infrastructure (with a railway gauge of 1520 and $1435 \mathrm{~mm}$ ) is of key importance, as is the related necessity of reloading goods on the Polish-Belarusian border. In geopolitical terms, Poland's location at the boundary of the European Union and the Eurasian Economic Union is important. The context of international safety and security is also highly relevant, as instability in the South Caucasus and in Ukraine leaves the New Eurasian Land Bridge as the fastest and safest transportation route connecting China with Europe (Jakubowski et al. 2017). In reality, however, the aforementioned rationales do not crystallise the position of Poland as the key partner in the implementation of the project. They also fail to guarantee substantial economic benefits for Poland, unless a number of additional conditions are met.

The primary objective of this article is to assess the potential role of Poland in the implementation of the Silk Road Economic Belt as a European hub supporting the transportation of goods on the route between China and the European Union via railway connections. We identify of the determinants and potential effects of Poland's involvement in the implementation of the Belt and Road Initiative in its political and geopolitical dimensions. Secondly, we conduct a detailed analysis of the existing and planned transportation infrastructure to facilitate cargo transport on the China-EU route. Thirdly, the article presents an analysis of commercial exchanges between Poland and China as well as existing cargo transport dynamics between China, Kazakhstan, and the European Union in which goods ultimately reach Poland and run through its territory. This allows us to evaluate the potential economic effects of implementing the BRI from the perspective of Poland in the context of the development of foreign trade, and particularly the export of Polish goods to Central and South-East Asia. 


\section{Belt and Road Initiative: Poland's perspective, role, and geopolitical dynamics}

\section{Defining the Silk Road Economic Belt}

The Belt and Road Initiative is a concept whose execution was initiated by China's President, Xi Jinping, in 2013 in Kazakhstan and Indonesia, where the "Belt" (Silk Road Economic Belt; SREB) means a network of interconnected land transport corridors, and the "Road" (Maritime Silk Road or 21st Century Maritime Silk Road) covers new marine routes (Guluzian 2017). It constitutes a relatively broad vision of trade connections between China and Europe, Asia, and Africa, aimed at the "development of employment and industries, creating new supply chains and value chain, and deepening the industrial integration between China and countries within the region" (Ministry of Commerce of People's Republic of China 2015). According to an action plan titled "Vision and Actions on Jointly Building Silk Road Economic Belt and 21st Century Maritime Silk Road" (National Development and Reform Commission 2015), the BRI encompasses five priority areas: policy coordination, facilities connectivity, unimpeded trade, financial integration, and people-to-people bonds. Liu et al. (2018) and Liu and Dunford (2016) present the BRI as an open, inclusive new international economic governance mechanism that seeks mutual benefits and paves the way for inclusive globalisation. Hovewer, the BRI project should primarily be seen as a multifaceted concept anchored in the domestic and foreign policy of China, emphasising the role of China as a country with global importance and based on Chinese political and economic interests (Misiagiewicz and Misiagiewicz 2016; Tekdal 2018).

This article does not discuss competing visions of the definition and characteristics of the Belt and Road Initiative. We identify two basic aspects of the BRI-one infrastructural, the other economic - taking into account the political and geopolitical conditions for the potential development of a Silk Road Economic Belt hub in Poland. Although the BRI has multiple components, in Poland and in many other countries, it is particularly perceived as a large-scale construction project targeting transport infrastructure and supporting the development of commercial contacts between China and other countries (Pantucci and Lain 2016; Pendrakowska 2018). In this context, the subject of this analysis is a route within the SREB called the New Eurasian Land Bridge Economic Corridor - a network of transport connections between China and the European countries, running through the territory of Kazakhstan, Russia, Belarus, and Poland, as specified in the first Action Plan published by the National Development and Reform Commission, the Ministry of Foreign Affairs, and the Ministry of Commerce of China in March 2015 (National Development and Reform Commission 2015).

\section{Poland's perspective and expectations}

The presentation of the concept of the Belt and Road Initiative was positively received and met with broad interest in Poland. Initially, the public discussion was dominated by the optimistic vision of Poland as the "land bridge" or "gateway" for China to the European Union. Poland was framed as a country that, owing to its beneficial geopolitical location at the boundary of two systems - the European Union (EU) and the Eurasian Economic Union (EEU) - could fulfil a key role in the implementation of the 
Chinese project and derive specific economic benefits from the initiative. If we consider the Silk Road Economic Belt as an intercontinental transport corridor, Poland could probably become a critical European hub through the development of infrastructure, and the development of the internal market could be stimulated by establishing intermodal reloading and logistics centres on its territory (Bachulska 2017).

On the one hand, Poland's increasing interest in cooperation with China results from increased Chinese engagement in Central and Eastern Europe under the 16+1 framework. On the other hand, it ties into Poland's efforts to diversify its economic links with countries outside the EU, motivated by the search for new economic partners and outlets for Polish entrepreneurs, as well as-according to Bachulska (2017) and Szczudlik (2016b) - by the changing role of the EU on the international scene. The intensification of political linkages with China came in tandem with an increase in economic relations, including the initiation of direct commercial connections - by sea from Shanghai to Gdańsk in 2010, and by land (railway) from Chongqing to Małaszewicze in 2011.

The extent to which the Belt and Road Initiative has commanded attention in Poland is related to successive governments' hope to implement certain economic objectives that are in accordance with the country's economic interest. First, Poland expects to further its development of transportation infrastructure (rail, road, aviation, marine, and inland), including intermodal logistics centres that would allow Poland to become a transport hub at a European scale (Polish Investment and Trade Agency 2017). This would be possible due to its favourable geographic location in the centre of Europe on the route of the New Eurasian Land Bridge Economic Corridor, and a network of transport connections with extensive reach in both the longitudinal and latitudinal dimensions. Second, Poland's involvement in the BRI project is aimed at supporting the expansion of Polish enterprises in the Chinese market and in other emerging markets in Asia, leading to an increase in the export of Polish goods and a reduction of the trade deficit with China (Majman 2015). The implementation of this goal is to be assisted by the "Go China" programme, launched in 2012 with the aim of encouraging Polish entities to be more active on the Chinese market and facilitating the initiation of trade contacts with business partners from China (Go China 2018). Third, Poland is expecting to attract Chinese investments, particularly in the industrial sector. In this area, Szczudlik (2016a) points to the synergistic relationship between the concept of the Belt and Road Initiative and Poland's Responsible Development Strategy, adopted in February 2017 and with benchmarks in 2020 and 2030 (Ministry of Investments and Development 2017). One of the activities aimed at achieving this goal was the creation of a special competence centre called the Poland-China Cooperation Centre (Majman 2015). Strategy emphasises the reindustrialisation of the country's economy. The implementation of the aforementioned objectives is aimed not only at stimulating economic development but also at increasing the importance of Poland in the political sphere at the regional (Central and Eastern Europe) and European level as a country with a key role to play in EU-China relations.

Poland's expectations are attuned to the Chinese offer, though not fully aligned with it. China desires cooperation particularly in the area of export, for the purpose of securing outlet markets for Chinese products and import of raw materials and technologies. China also wants the lifting of customs barriers for exported goods, preferential treatment of its business activities in Special Economic Zones, and simplification of the 
tender procedure for Chinese enterprises. From China's perspective, the elimination of infrastructural "bottlenecks" limiting transport capacities is also of great importance (Misiagiewicz and Misiagiewicz 2016; Szczudlik 2016a). Therefore, pursuant to China's approach, the role of Poland in the context of the BRI primarily involves transit issues. According to Bachulska (2017), Poland would firstly become an infrastructural base supporting transport to other target locations in Europe through a welldeveloped network of routes. It would constitute an important component of China's plans, albeit as part of a broader network of connections. From China's point of view, Poland's greatest advantage is its geographical location on the easiest and fastest land route connecting China with the EU, where trains cross only two customs borders (between China and Eurasian Economic Union and the European Union) (Bachulska 2017).

\section{Institutional frames of Polish-Chinese cooperation}

A particular intensification of Polish-Chinese relations has been observed in recent years via direct channels and at the subregional level, by means of the CEE $16+1$ framework. This initiative, established in Warsaw in 2012, covers China and 16 countries of Central and Eastern Europe (van der Putten et al. 2016). ${ }^{2}$ The institutional framework for Polish-Chinese bilateral political and economic cooperation in the context of the BRI is currently constituted by a number of arrangements and agreements concluded during meetings of the heads of both states, in China in 2015 and in Poland in 2016. The scope of these meetings pinpointed basic areas of interest in Polish-Chinese cooperation, with particular emphasis on the development of the transportation network, improvement of transport between China and Europe, support for commercial exchange, and inflow of investments (Szczudlik 2016a). Insofar as support for the BRI is concerned, one key document is the "Memorandum of Understanding on the Belt and Road Initiative", signed in November 2015 by Polish President Andrzej Duda and the President of the People's Republic of China, Xi Jinping, as well as a number of agreements supporting the financing and implementation of Polish-Chinese infrastructure investments (Szczudlik-Tatar 2015; Bachulska 2017). Xi Jinping's visit to Warsaw in June 2016 brought another series of agreements, this time regarding the implementation of infrastructure projects, development of trade, and support for investment activities (Ministry of Development of Poland 2018). Later meetings - including a visit to China by the Polish Minister of Foreign Affairs, Witold Waszczykowski-were devoted to the issue of financing the construction of the Central Airport (a planned mega-airport in Central Poland) and the development of the BRI Action Plan (PM of Poland 2018). Moreover, Poland's engagement as a founding member of the Asian Infrastructure Investment Bank (AIIB) could be perceived as an expression of Poland's more proactive approach to cooperation with China. The analysis by van der Putten et al. (2016) suggested that, at some stage, out of approximately a dozen European Union states involved in the implementation of the Silk Road Economic Belt and covered by the analysis, Poland was characterised by the most

\footnotetext{
${ }^{2}$ The 16+1 initiative covers China, 11 EU Member States (Bulgaria, Croatia, Czech Republic, Estonia, Hungary, Latvia, Lithuania, Poland, Romania, Slovakia, Slovenia), and seven candidate countries (Albania, Bosnia and Herzegovina, North Macedonia, Montenegro, and Serbia). In 2019, Greece also joined this group.
} 
advanced cooperation with regard to initiatives that corresponded with the general thrust of China's Belt and Road Initiative (Table 1). However, the heightened diplomatic activity observed in 2015 and 2016 brought no breakthrough-except in the declarative sense - in the scope of implementing the objectives posited in the BRI framework. The agreements that were finalised identified certain areas of cooperation, but did not precisely specify the mechanisms of their implementation. Secondly, the lack of real progress resulted from the gradual distancing of the Polish government from greater engagement with China. This, in turn, was prompted by doubts about the potential benefits and threats that the development of the Belt and Road Initiative could bring to Poland in the context of the growing trade deficit with China. Undoubtedly, the ambiguous position of the European Union and Poland's traditional allegiance to the transatlantic alliance with the USA (Górski 2017), as well as the ambitions shared by the USA and Poland to increase the former's military presence in the latter, also had an indirect impact on this situation.

Dialogue on the highest level allows governments to initiate and support economic cooperation by providing appropriate conditions and a favourable political atmosphere. Strengthening business contacts with partners from China, however, also requires political support on the part of regional and local authorities in order to legitimise the cooperation between business partners (Skorupska and Szczudlik-Tatar 2014). Due to the potential benefits that derive from cooperation with China, numerous attempts have been undertaken on the regional and local levels to develop an institutional framework of cooperation with Chinese partners (van der Putten et al. 2016). At the beginning of 2019, 13 Polish-Chinese agreements on cooperation were concluded on the regional level, while several dozen were signed on the local level. In some cases, this translated into a return to economic cooperation initiated as early as the 1950s. Although the thematic scope of the aforementioned agreements encompasses a broad range of issues, the priority in each case is assigned to economic cooperation. Whereas we have already observed certain effects stemming from this cooperation (in Łódź and Gdańsk, among others), representatives of local self-governments still share the opinion that cooperation with partners from China rarely leads to measurable results. It usually culminates in declaratory documents that are not implemented in reality (Skorupska and SzczudlikTatar 2014).

\section{Geopolitical context}

One of the most important instruments that facilitate the implementation of China's interests in Central and Eastern Europe (CEE) is the " $16+1$ " cooperation forum, initiated in 2012. Over the past few years, the initiative has been used by China mainly to accelerate cooperation on the BRI. As a result, according to some analysts and scholars, it is the CEE that has constituted the key area of interest and an important link in China's overall global outreach so far (Góralczyk 2017; van der Putten et al. 2016; Song 2019; Vangeli and Pavlićević 2019). On the other hand, the gradual differentiation of the positions of individual CEE countries towards China's involvement in the region have led to different dynamics in China's political and economic cooperation with specific partners in the region. In the case of Poland, the Chinese side has focused primarily on investment activities (Song 2019). In light of the discussion on possible non-economic reasons to promote cooperation with China (Kavalski 2019; Jakimów 


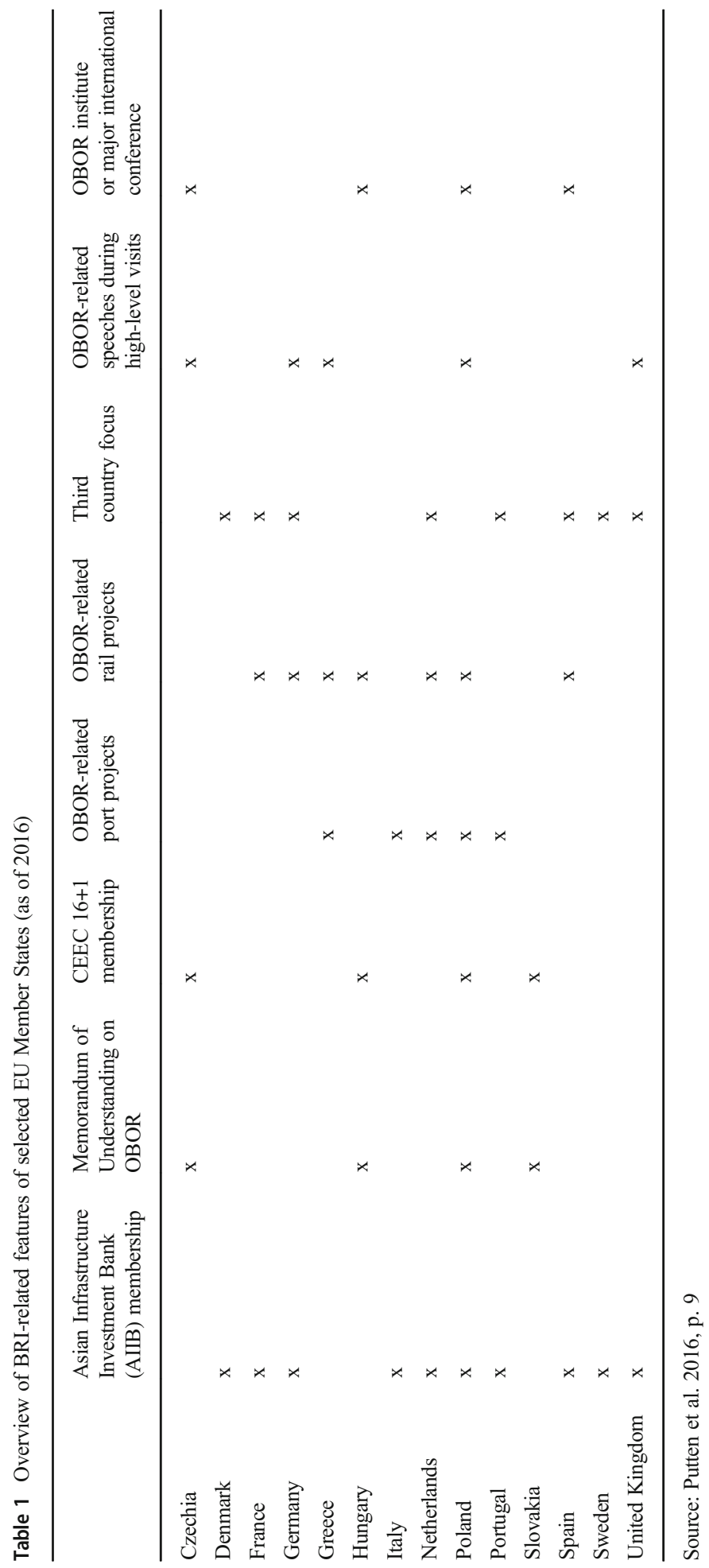


2019), it seems that the prevailing aim in Poland is to maximise the country's economic benefits while simultaneously reaffirming its assertiveness in the geopolitical sphere.

China's actual objective, however, is a gradual increase in the export of Chinese products to the countries of the European Union (Kratz 2016). The EU has been China's most important trade partner for approximately a dozen years, among others due to the country's commercial trade with the states of Western Europe. One of the serious problems facing Polish-Chinese cooperation under the 16+1 framework is the perception of the initiative by EU countries in Western Europe as a tool to divide and fragment the community, aimed at the creation of a local zone of Chinese influence in Europe (Fallon 2015; Stanzel 2016, Song 2019). Contrary to suggestions by Wang (2015) and Minghao (2016) concerning the numerous benefits that would accrue to the European Union from the implementation of the Silk Road Economic Belt (e.g. strengthened political and economic connections in the Eurasia, stability and growth, increased importance of Europe on the global scene through the rebalancing of transatlantic relations), Casarini (2016) argues that the BRI is primarily a challenge for the EU. According to the European Commission (2016), the main problem is the lack of reciprocity in the rules governing trade exchanges between the EU and China, including the policy of China promoting domestic production and discriminating its foreign counterpart, in addition to considerable state interventionism. Due to all this, according to Holslag (2017), the Silk Road Economic Belt is a threat to the interest of the countries of the European Union, including Poland, and will lead to a gradual increase in imports from China, solidifying the unfavourable balance in commercial exchange between the two economic powerhouses.

As a result of the geographical path of the New Eurasian Land Bridge, the implementation of the development plan targeting transportation infrastructure in Poland and its transformation into a dedicated Silk Road Economic Belt hub is also influenced by the relations between China, the Eurasian Economic Union, and the European Union (Kaczmarski 2017). China emphasises the strategic importance of cooperation with Russia and member states of the Eurasian Economic Union (EEU, i.e. Russia, Belarus, Kazakhstan, Kyrgyzstan, and Armenia), developed under its " $5+1$ " initiative (Hu et al. 2017). This is supported by the fact that the BRI was inaugurated in the capital of Kazakhstan. One should recall, however, that the EEU is a geopolitical project developed by the Russian Federation, aimed not only at the political and economic integration of the post-Soviet states but also at providing Russia with an opportunity to balance the influence of the European Union and China in Central Asia (Gallo 2014; Ploberger 2017). Although Russia currently seems to express a willingness to cooperate within the scope of the Chinese project, the traditionally competitive character of Russian-Chinese relations renders the future of cooperation between the two countries uncertain (Wilson 2016). In its offer for the countries of Central Asia, China also underlines development opportunities related to the Belt and Road Initiative (Liu and Dunford 2016), although Diener (2015) and Summers (2016) suggest that part of them perceive the BRI as a manifestation of neo-colonial activity, and the role of a transit country is not an attractive vision of development for them. It is also worth considering the context of relations between Russia and the European Union, including Poland, particularly in the context of EU sanctions imposed on Russia (and Russian countermeasures) in relation to the conflict in Ukraine. This currently constitutes the greatest barrier to economic cooperation for both parties. 


\section{Transport infrastructure and connectivity}

\section{New Eurasian Land Bridge Economic Corridor}

In terms of infrastructure, the New Eurasian Land Bridge Economic Corridor, running through Kazakhstan, Russia, Belarus, and Poland, is the railway line that currently constitutes the shortest and safest land connection linking Eastern China and Central Asia with Western Europe. The formal launch of the main line in 2011 was made possible, among others, by considerable investments in Western China (Debreczeni 2016; Tarkhov 2018). Attempts to set up a robust transportation network between China and the EU had already been undertaken several years earlier, following several pre-existing routes, specifically the Trans-Mongolian, Trans-Manchurian, and TransSiberian routes. In 2008, the first direct connection between China and Germany was launched (through Mongolia) (Rodrigue et al. 2017). Its route, the high costs of transiting through Russia, and the limited capacity of the infrastructure (particularly on the Trans-Siberian route, per Bykadorov 2017) did not contribute to the expected increase in shipping to West Europe, as a result of which an additional transportation route had to be launched.

The main route of the Silk Road Economic Belt is specified in a document entitled "Development Plan of China-Europe Freight Train Construction (2016-20)", issued by the Office of the Leading Group on the Construction of the Belt and Road (Development Plan of China-Europe Freight Train Construction (2016-20) 2018). The actual routes of the implemented transportation arteries often deviate from the main one and feature numerous branches. The city of Lianyungang on the Yellow Sea marks the beginning of New Eurasian Land Bridge Economic Corridor in China, while the European endpoint is Rotterdam in the Netherlands (Fig. 1). The route runs through the territory of Northwest China, East and North Kazakhstan, the European part of Russia, Belarus, Poland, Central Germany, and the Netherlands. The length of the defined section is approximately $11,100 \mathrm{~km}$, including the distance between Lianyungang and Warsaw, which covers approximately $9860 \mathrm{~km} .^{3}$ Several large urban centres in China can be regarded as hubs interconnected with the main route of the New Eurasian Land Bridge Economic Corridor. The first one is Chongqing, from where the first direct train departed on the new route in 2011, crossing the territory of Poland en route to Germany. The other cities include Chengdu, Xi'an, Zhengzhou, Wuhan, Changsha, Hefei, Yiwu, and Xiamen (H\&T 2018; Beijing Trans Eurasia International Logistics 2020; DHL Global Forwarder 2020). Differences in the track gauge constitute a serious development barrier affecting the efficiency of rail traffic along the entire corridor. They force freight managers to reload goods twice, on the Chinese-Kazakh and Belarusian-Polish border (He 2016). China and the countries of Western Europe have standard gauge $(1435 \mathrm{~mm})$ track infrastructure, while post-Soviet countries have broad gauge networks $(1520 \mathrm{~mm})$. One solution that reduces reloading time to the maximum is intermodal container transport, which is commonly used and has proven efficient in cargo transport between Asia and Europe. Prospectively, aligning the track

\footnotetext{
${ }^{3}$ Values calculated based on a group of cartographic sources: Atlas Zheleznykh Dorog Stran OSZhD... 2013; Fahrplanauskunft für Bahn and Zugreisen mit Preisvergleich 2018; Stankiewicz and Stiasny 2014; Zhongguo Tielu Dituji 2015.
} 
gauge along the entire length of the New Eurasian Land Bridge is unlikely. The need to reload all containers, particularly at the external border of the EU, can therefore negatively affect the modal structure of transport that has already reached Europe.

Several alternative infrastructural transportation routes exist between Asia and Europe in addition to the New Eurasian Land Bridge Economic Corridor (Fig. 1). The first one is the northern corridor that includes the above-mentioned Trans-Mongolian, Trans-Manchurian, and Trans-Siberian routes. This is still a convenient option for transport from and to Northeast China and the coastal regions, providing a key connection for cities like Harbin, Shenyang, and Suzhou (Wang et al. 2018). In Moscow, the corridor connects with the New Eurasian Land Bridge and provides additional cargo streams for the section leading to the border with Poland.

Other variants are better tailored to serve the Balkans. Some of them are less safe, however, or temporarily unavailable due to the unstable geopolitical situation in the region. The main route of the southern corridor runs through Kazakhstan, Uzbekistan, Turkmenistan, Iran, and Turkey. The existing infrastructure allows for the transportation of goods on the route from Kazakhstan via Russia (Volgograd) towards Ukraine as well. The timing and circumstances of the launch of those routes depend on the situation in Eastern Ukraine and are contingent on the normalisation of international relations with Iran. Thus, other alternatives have emerged, though they encounter a perennial obstacle in the form of the need to reload goods several times due to the maritime transfer they entail. One of these routes runs from Kazakhstan through the Caspian Sea, Azerbaijan, Georgia, and the Black Sea to Bulgaria, where the TEN-T ${ }^{4}$ Orient/East-Med Corridor begins, or (optionally) to Southern Ukraine. In 2017, the option to omit the Black Sea transfer through the Baku-Tbilisi-Kars Railway emerged and has been in active use ever since (Suleymanov 2017). The line runs from Azerbaijan and Georgia to Turkey, bypassing the former connection through Armenia, which maintains poor relations with its neighbours. From the Eurasian point of view, Poland constitutes a natural gateway to Western Europe. Poland is the confluence point for broad and standard gauge infrastructure as well as the corridors of the TEN-T network - the North Sea-Baltic Corridor and the Baltic-Adriatic Corridor. However, not all rail routes toward Kazakhstan and China running north from the Black Sea have to run through Poland when they omit Ukraine. Eliminating the need to change the track gauge allows for the involvement of the Baltic states and Finland. Goods can be transported from there by sea or lorries to Western Europe.

\section{Transport infrastructure: current state and planned development}

Poland's rail network is currently approximately $20,000 \mathrm{~km}$ long, approximately $60 \%$ of which is electrified. Railway lines covered by the international $\mathrm{AGC}^{5}$ and $\mathrm{AGTC}^{6}$

\footnotetext{
${ }^{4}$ TEN-T-Trans-European Transport Network. Europe-wide network of rail lines, roads, inland waterways, maritime routes, ports, airports, and intermodal terminals. TEN-T comprises the Core Network (the most important connections, to be completed by 2030) and the Comprehensive Network (covers all European regions, to be completed by 2050). The backbone of the Core Network is represented by nine corridors (European Commission 2013).

${ }^{5}$ AGC-European Agreement on Main International Railway Lines, signed in Geneva on May 31, 1985.

${ }^{6}$ AGTC - European Agreement on Important International Combined Transport Lines and Related Installations, signed in Geneva on February 1, 1991.
} 


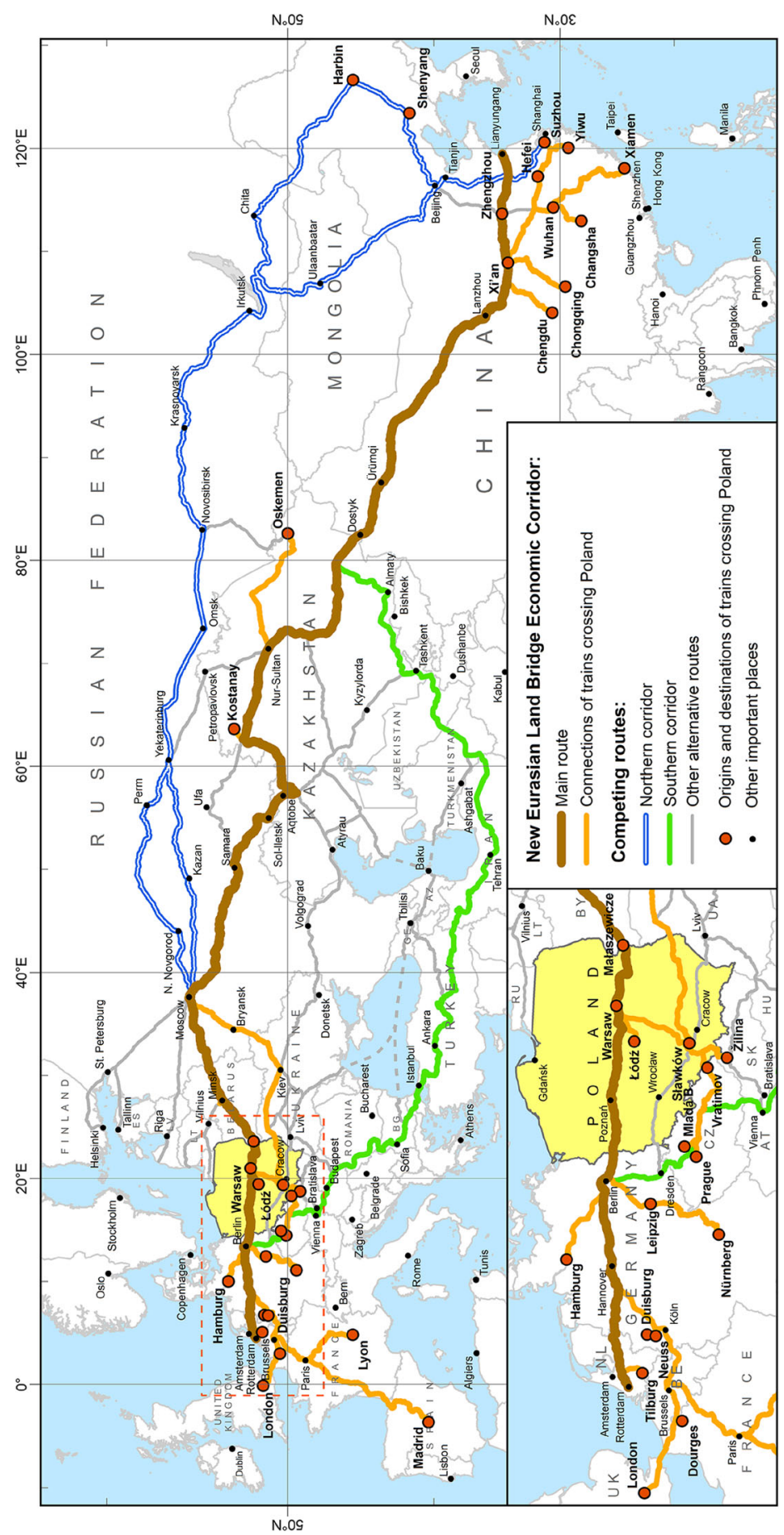

Fig. 1 Course of the New Eurasian Land Bridge Economic Corridor overlaid on Eurasia and competing routes. Own elaboration based on Atlas Zheleznykh Dorog Rossii 2015, Atlas Zheleznykh Dorog Stran OSZhD... 2013, Zhonguo Tielu Dituji 2015, H\&T 2018, Belintertrans 2018, Belarusian Railway 2018 


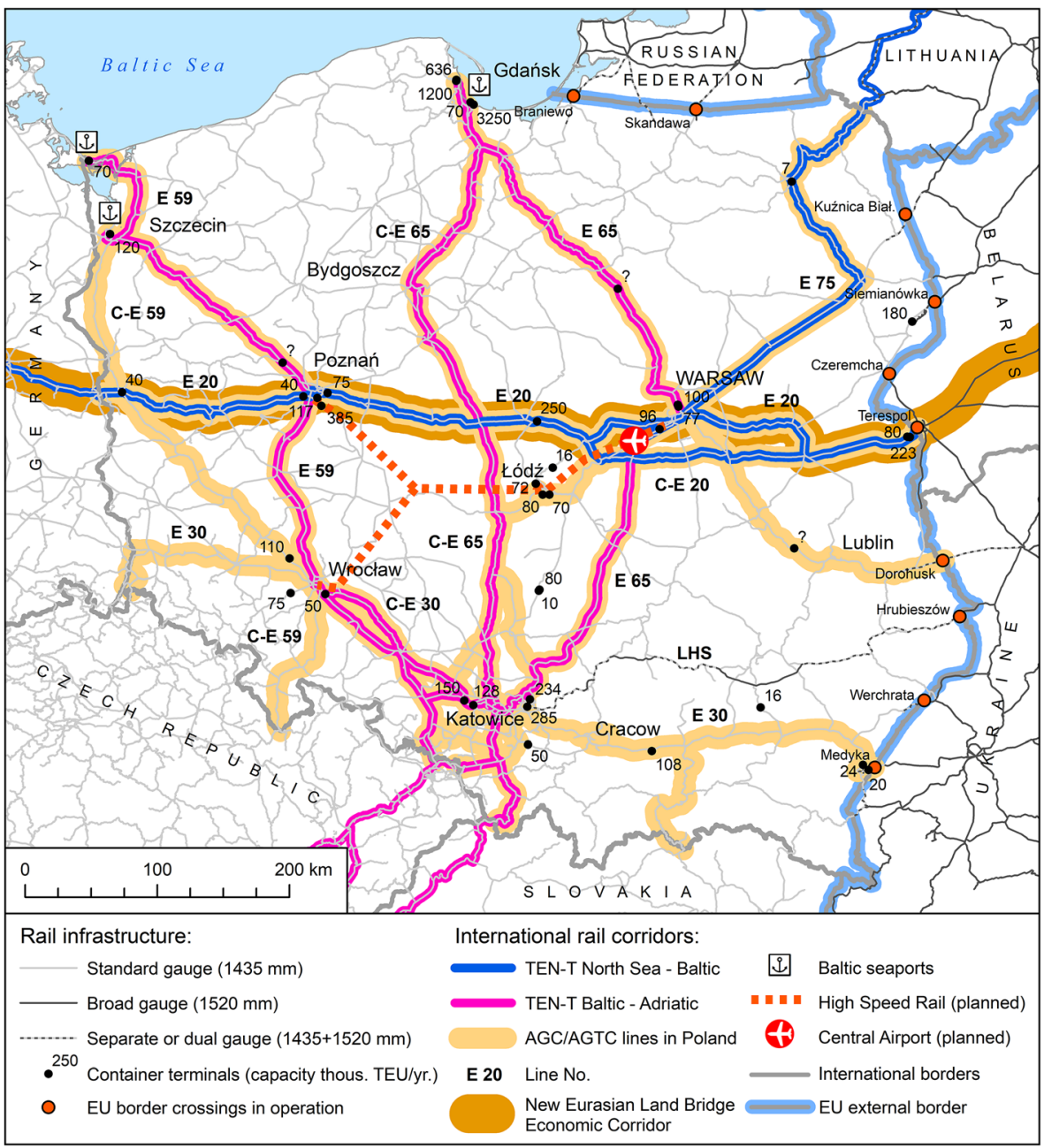

Fig. 2 Key linear and point rail infrastructure in Poland with the potential to support transport along the New Eurasian Land Bridge Economic Corridor. Own elaboration based on PKP PLK 2018; Stankiewicz and Stiasny 2014; UTK 2018

agreements have respective lengths in Poland of 2972 and $4278 \mathrm{~km}$. Part of these lines is included in the core TEN-T network (Fig. 2). These are sections of key importance for cargo transport, although not all of them meet the relevant technical requirements as of late 2017. Assistance via EU funding is of high importance in the process of modernising this infrastructure. Since 2004, considerable progress has occurred in improving the state of the existing infrastructure. The share of railway lines that are in good condition has increased from 25 to 60.8\% (PKP PLK 2005; PKP PLK 2018).

The New Eurasian Land Bridge runs through the territory of Poland on the E 20 railway line (Terespol-Warsaw-Poznań-Rzepin). Its technical parameters meet the requirements stipulated by international agreements. It also has favourable connections with the industrialised south of the country and seaports in the north, including 
Deepwater Container Terminal in Gdańsk - the largest in the Baltic Sea - thanks to the modernised E 65 line.

Poland mostly has standard gauge infrastructure, and only approximately $500 \mathrm{~km}$ of the network is broad gauge lines, most of which are concentrated in trans-border connections to facilitate border crossings with Russia, Belarus, and Ukraine. The exception is the LHS line (the Broad Gauge Metallurgy Line), which has a length of $395 \mathrm{~km}$ and connects the Polish-Ukrainian border with Sławków in Upper Silesia, a region with a high level of industrialisation. Built in the late 1970s, it was originally used for the transportation of iron ore from the Soviet Union to Poland and sulphur in the opposite direction (Ciemnoczułowski 2009). Its potential is currently limited by low capacity (single track) and diesel traction. There are plans to electrify the line, with prospects of extending it to the west - the Czech Republic and Austria. In June 2018, PKP LHS - the owner and operator of the line-test-ran a train to China from the Euroterminal in Sławków via Ukraine, Georgia, Azerbaijan, and Kazakhstan (Zasiadko 2018). In November 2018, the same company signed an agreement with Chinese partners to establish a fixed route (PKP LHS 2018). The first train from Xi' an arrived in Sławków in January 2020. The train's path covered the main section of the New Eurasian Land Bridge and then a branch from Moscow via Bryansk and the Ukrainian railway network. The whole trip took 12 days (PKP LHS 2020). Although at present only one train runs along this route per month (Table 3 ), it is an attractive option with strong potential to develop this connection in the future. The Russian initiatives to develop Eurasian connections do not include LHS, however, pointing to the alternative broad gauge route in Slovakia (Uzhhorod-Košice) instead, with a possibility of extending it to Vienna (Atlas Zheleznykh Dorog Stran OSZhD... 2013). The current geopolitical situation, however, limits the prospects for its use and expansion.

In terms of the infrastructural efficiency of the SREB, the infrastructure near the eastern border of Poland (which at the same time constitutes the external border of the European Union) is of key importance. Border rail traffic toward Belarus occurs through four border crossings. For the New Eurasian Land Bridge, the TerespolBrest crossing is the most important, on line E 20. The Polish-Ukrainian border section has six railway crossings (including four active ones), with Medyka-Mostiska, located on line E 30, being the most important one for cargo transport. The Hrubieszów-Izov crossing is another important juncture on the border, supporting the LHS line. Due to the Ukrainian crisis, the potential of these border points is grossly underexplored.

The territory of Poland includes 40 container terminals with access to the railway network, most of which belong to the AGC/AGTC corridors. Six of them are located within seaports, among which those with the greatest transshipment capacity in Poland are the Deepwater Container Terminal Gdańsk (3,250,000 TEU/year), the Baltic Container Terminal Gdynia (1,200,000 TEU/year), and the Gdynia Container Terminal (636,000 TEU/year). Seven terminals provide support for rail transport associated with the New Eurasian Land Bridge. The largest of these-PCC Intermodal Kutno (250,000 TEU/year) - is located in the centre of Poland. Two additional important junctures supporting the New Eurasian Land Bridge are the terminals at the PolishBelarusian border crossing at Terespol-Brest-Terminal Centrum Logistyczne Małaszewicze and EUROPORT Małaszewicze Duże (with a total transshipment capacity of 303,000 TEU/year). The remaining terminals facilitate connections with other European Union countries or play the role of domestic hubs supporting, in particular, 
connections with the marine terminals of Gdańsk and Gdynia as well as distribution of containers to recipients by lorries. This group includes Euroterminal Sławków (285,000 TEU/year), which constitutes the end point of the LHS line, as well as others.

Considering the geographic distribution of the border crossings and container terminals, the state of the infrastructure, and the current geopolitical situation, the Terespol-Brest border crossing (together with the Małaszewicze terminal) should be recognised as critically important for the New Eurasian Land Bridge. If EuropeanAsian traffic is overconcentrated on the Polish-Belarusian border, the role of other points on the border, complete with old reloading infrastructure and broad gauge tracks penetrating about a dozen kilometres into the territory of Poland, could also increase. Other locations on the border with Ukraine can also gain importance should the geopolitical situation change or should the southern corridor of the Silk Road Economic Belt, which will leverage navigation on the Caspian and Black Seas, be activated.

It should be emphasised that Poland is currently a country that operates large volumes of transit between Russia, Belarus, and Ukraine and Western Europe. These streams primarily take the form of road transport, and their main direction is from Russia through Latvia and Lithuania to Poland, and further through Warsaw to Germany. The traditional route through Belarus is of relatively less importance. The foundations of this transport system are geopolitical. Operators prefer to directly cross the border between Russia and the European Union and then continue with no further border controls (Komornicki 2008; Komornicki 2019). Moreover, the strong position of road transport operators from Lithuania and Poland in the facilitation of transit in Eastern Europe cannot be ignored. These operators can also be expected to seek a share of the container distribution market operating between the New Eurasian Land Bridge to Europe. They will likely take a competitive stance toward further railway transport to Germany, particularly in Poland and the neighbouring countries. Whether Poland becomes the hub of European-Asian cargo transport can therefore depend on the results of a competitive game with specific modal (rail and road transport, sea transport) and geographical characteristics (terminals and carriers from Poland, and subjects from Belarus, Russia, and the Baltic states).

By 2023 (the end of the current EU programming period), Poland intends to have a fully modernised primary rail network. The construction of the Polish High-Speed Rail (HSR) network between Warsaw, Poznań, and Wrocław, whose inauguration is to take place by 2030, will help to free part of the capacity of the E 20 line, currently used simultaneously for cargo and passenger transport. Another major construction project, to be realised in tandem with the HSR, is the Central Airport. The airport is slated to fulfil the function of a regional transport hub in Central and Eastern Europe. Thus, one opportunity for Poland, based on the development of the railway and road infrastructure, could be the creation and operationalisation of an efficient distribution system for goods imported via the New Eurasian Land Bridge within Central and Eastern Europe and Scandinavia, with potential feeder connections implemented in Polish ports. Poland's participation in the distribution of goods in Western and Southern Europe also should not be excluded (particularly given the overloaded state of Atlantic ports). In the last decade, Poland has considerably expanded its road infrastructure. Motorways and expressways connect its road system with Germany, the Czech Republic, and Ukraine, as well as with ferry terminals in Gdańsk and Gdynia (in the direction of 
Scandinavia). A connection with Lithuania, which comprises part of the route connecting Finland, the Baltic States, Poland, and Germany (the Via Baltica), is under construction, and another with Slovakia is planned (Via Carpatia; Rosik et al. 2018). The latter will lead further through Hungary, Romania, and Bulgaria to the Greek port of Piraeus, becoming the flagship Chinese investment in Europe under the BRI project.

In its infrastructural dimension, one of the most important aspects of the planned Polish-Chinese cooperation under the aegis of the Silk Road Economic Belt is the involvement and support of China in the expansion of transport infrastructure in Poland, allowing for efficient transportation of Chinese goods to other EU countries. From Poland's perspective, the task should place special emphasis on engaging Chinese capital to implement infrastructure investments; from China's perspective, it should entail the possibility of obtaining attractive construction deals for Chinese enterprises. So far, however, China has not presented an attractive development offer to $\mathrm{CEE}$ countries that belong to the EU, including Poland. According to Jakóbowski and Kaczmarski (2017), there are two basic reasons for this. The first one relates to the financial aspects of development. Poland, as a country that is part of the EU, has broad access to different forms of investment financing. This frequently takes the form of a partial subsidy. Structural funds are an example of such a subsidy, as illustrated by the TEN-T programme, which is aimed at the development of transport infrastructure. The Chinese offer is simply unattractive in comparison. Secondly, the legal-political context is also of key importance. The financing model preferred by China-combining credit offers with designating the contractor for investments while omitting standard legal tender proceedings (and the concomitant requirement to obtain governmental guarantees) - is at odds with EU law (Jakóbowski and Kaczmarski 2017). We should expect an increase in China's interest in implementing infrastructure investments in Poland in the coming years, centering both on issues pertaining to their financing as well as their implementation (Kaliszuk 2016). The results of a study by Liu et al. (2017) show that Chinese construction companies, supported by the Chinese authorities, gradually increase their involvement in the territory of BRI countries. On the one hand, this expansion results from China's continued search for new markets; on the other, it is an evident manifestation of the implementation of a concerted governmental strategy (Kowalski 2017). The unintended consequences for Poland of such involvement on the part of China are very difficult to predict at this time.

\section{Economic implications for Poland}

\section{International trade by mode of transport}

In the twentieth century, transport of goods between East Asia and Western Europe still occurred exclusively through two modes of transport - cargo aviation (more expensive but faster) and marine transport (cheaper but slower). The activities undertaken by China and the countries of Western Europe enabled them to engage a third mode - rail transport, permitting shorter shipping times than by sea and lower cost compared with aviation. In aviation transport, considering the clearance time, transport from China to Europe lasts approximately 3-4 days and is twice as expensive as rail transport. Marine transport requires approximately 30-40 days, including delivery and collection of the 


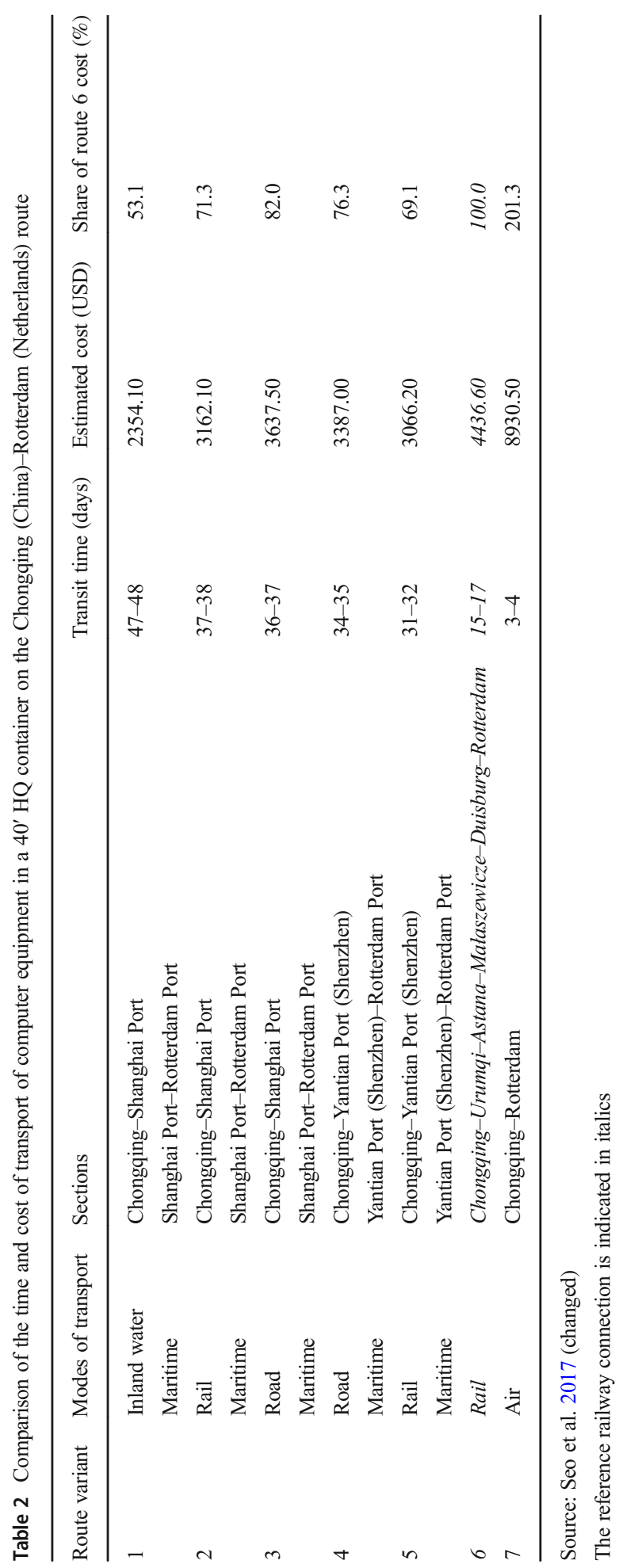




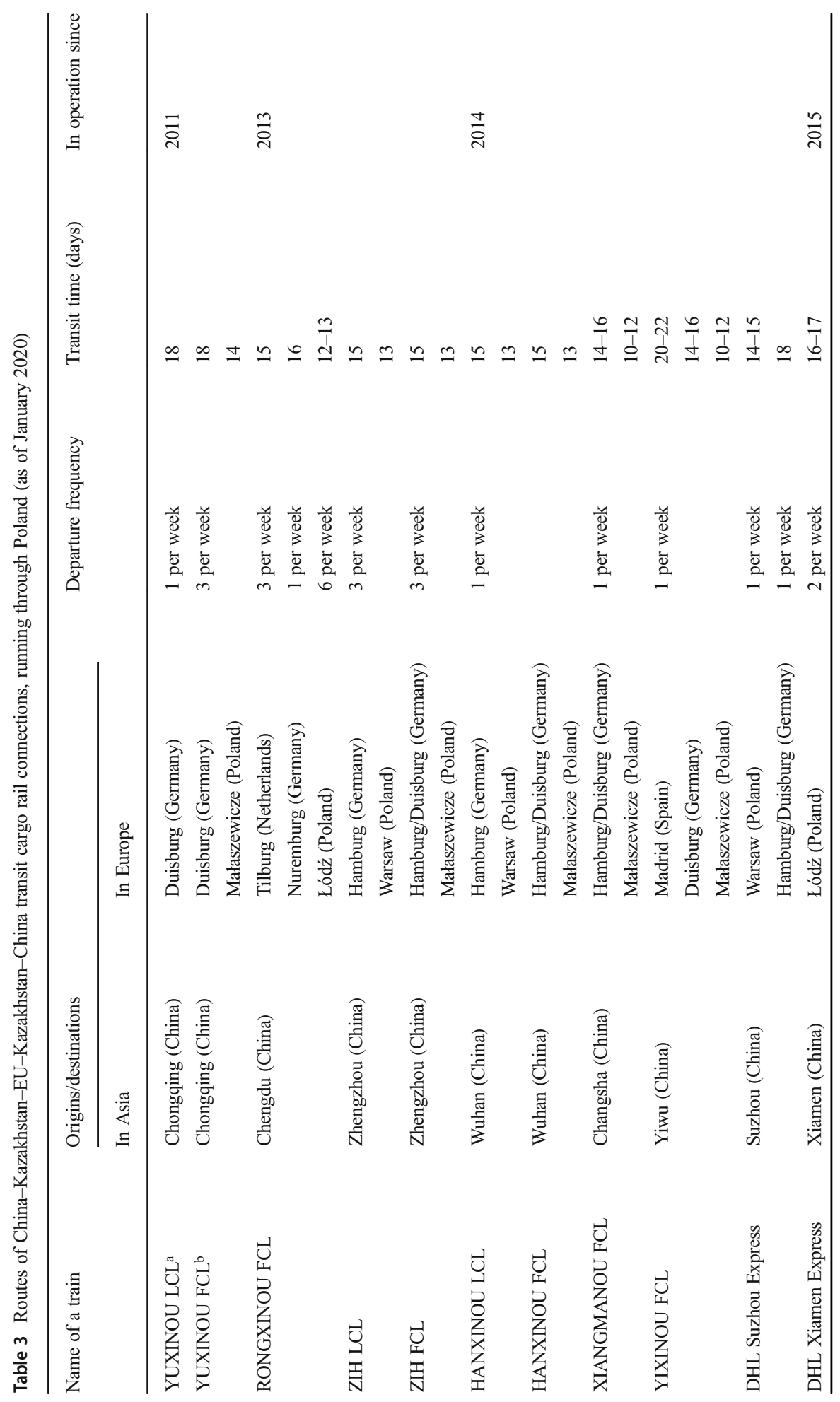




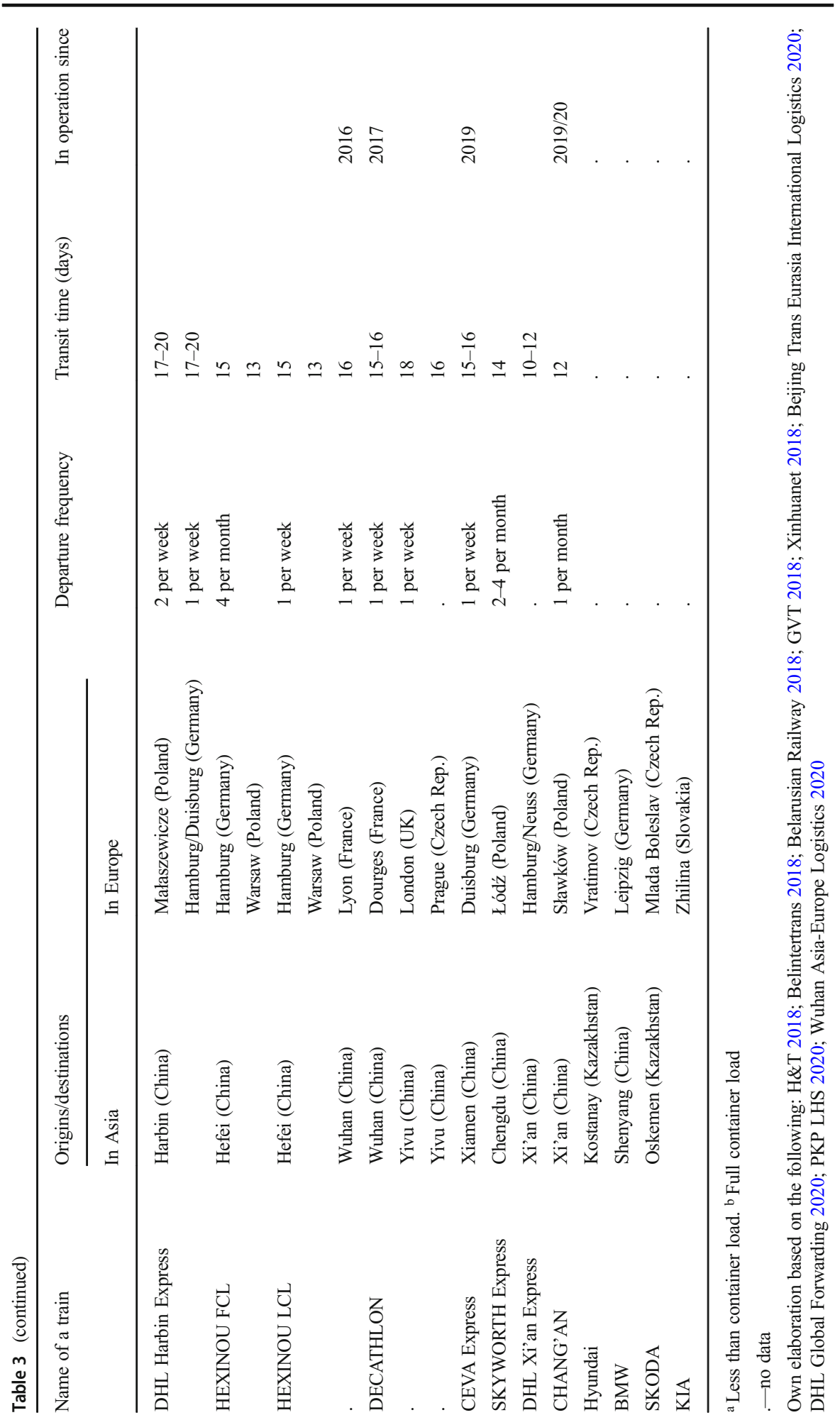


cargo from the port. The total costs constitute $50-80 \%$ of those incurred when the operator uses rail transport exclusively (Table 2; Seo et al. 2017). Moreover, the rail option offers more flexibility in terms of changes in demand for transport and is less dependent on weather conditions. One container ship used on the Asia-Europe route can carry at least 10,000 TEU, and the largest ships carry more than 20,000 TEU (OOCL 2018). The load capacity of a train is only approximately 90 TEU (Rodemann and Templar 2014). Therefore, railway connection should be treated as a complementary variant for a selected segment of goods, and not a substitute for current sea routes.

With regard to existing cargo shipments routes between China, Kazakhstan, and the European Union that reach Poland and run through its territory, we can identify 26 separate routes (Table 3). However, a certain imbalance occurs between the two directions of transport. Managing the return connection to Kazakhstan and China is a serious organisational challenge. The deficit is partially remedied by permanent connections transporting parts for the production of cars from European factories to those located in Asia and facilitating the export of food products.

Each week, 20-30 trains on the China-EU-China route run through Poland. From Poland's point of view, all of them are transit connections, with target stations located in Western Europe, including Germany, the Netherlands, France, Great Britain, and Spain. Part of the rolling stock carries containers to target stations in Poland, including Małaszewicze, Warsaw, and Łódź. The development of the aforementioned cargo rail connections running through Poland is reflected in the rapidly growing importance of rail as a mode of transport in trade with China. The total value of goods transported from China to Poland by rail amounted to 25 million EUR in 2013, 249 million EUR in 2015, more than 1 billion EUR in 2017, and almost 1.8 billion EUR in 2019. The relative share of rail transport in the total amount of goods imported from China rose from $0.3 \%$ in 2013 to $8.6 \%$ in 2019 . One can also observe a steady increase in the importance of export to China by rail-its value rose from 2 million EUR in 2013 to 160 million EUR in 2019, which accounted for $0.1 \%$ and $6.1 \%$ of the value of all goods transported from Poland to China, respectively (Eurostat Database 2020).

In the course of developing a hub for the Silk Road Economic Belt, Poland can encounter competition from neighbouring countries to the east and north that have

Table 4 Foreign trade turnover between Poland and the countries of Central Asia in 2019

\begin{tabular}{|c|c|c|c|c|c|}
\hline \multirow[t]{2}{*}{ Country of origin/consignment } & \multirow{2}{*}{$\begin{array}{l}\text { Import (origin) } \\
\text { Million USD }\end{array}$} & \multicolumn{2}{|c|}{ Import (consignment) } & \multirow{2}{*}{$\begin{array}{l}\text { Export } \\
\text { Million USD }\end{array}$} & \multirow{2}{*}{$\begin{array}{l}\text { Balance } \\
\text { Million USD }\end{array}$} \\
\hline & & Million USD & $\%$ & & \\
\hline China & $32,615.41$ & $21,136.66$ & 64.8 & 2969.56 & $-29,645.85$ \\
\hline Russian Federation & $16,196.18$ & $16,869.68$ & 104.2 & 8328.89 & -7867.29 \\
\hline Kazakhstan & 1458.12 & 160.31 & 11.0 & 598.15 & -859.96 \\
\hline Uzbekistan & 53.32 & 43.35 & 81.3 & 180.86 & 127.54 \\
\hline Mongolia & 1.71 & 1.31 & 76.4 & 27.54 & 25.83 \\
\hline Kyrgyzstan & 1.19 & 0.29 & 24.5 & 56.51 & 55.32 \\
\hline Turkmenistan & 1.09 & 0.40 & 37.3 & 25.08 & 23.99 \\
\hline Tajikistan & 0.87 & 0.73 & 83.1 & 17.10 & 16.23 \\
\hline
\end{tabular}

Own elaboration based on Statistics Poland 2020 

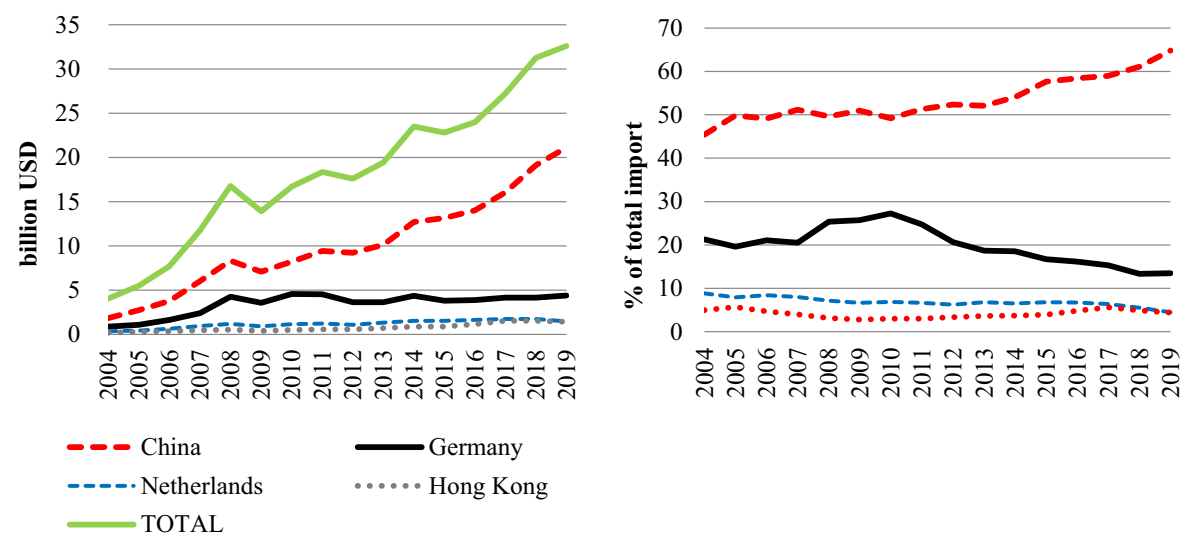

Fig. 3 Dynamics of import of Chinese goods to Poland by main country of consignment. Own elaboration based on Statistics Poland 2020

broad gauge rail tracks (Bulis and Skapars 2014). One serious threat is the possibility that freight trains might be unloaded earlier and the goods transported further to Western Europe by lorry. Two connections with China currently end or begin their course in Brest in Belarus, right at the border crossing with Poland in Terespol (the "Kazakhstan Vector" and "Mongolian Vector" trains). The Baltic states also have their own connections: Latvia with Kazakhstan ("Baltic Wind") and Lithuania with China (“Saule”) (Belarusian Railway 2017).

\section{Trade turnover with China and countries of Central Asia}

The European Union has a strongly negative trade turnover with China. China's only large partner with comparable trade is Germany. Therefore, in the case of rail transport between East Asia and Germany, it is possible to carry full loads in both directions. Among China's ten main commercial partners in the European Union, at least seven can use rail connections through Poland (Germany, the Netherlands, France, Great Britain, Belgium, Sweden, and the Czech Republic). Together with Poland, in 2019, these countries accounted for approximately $76.9 \%$ of the trade turnover between EU and China. Moreover, they are characterised by high rates of growth, particularly in the export category. In this context, the import of Chinese goods into Poland has increased particularly fast (eightfold in the period from 2004 to 2019; Eurostat Database 2020).

Poland's commercial turnover is generally characterised by a negative balance, both vis-à-vis China (industrial goods of various kinds) and Russia and Kazakhstan (mainly due to the import of raw materials). At the same time, Poland has positive turnover with the countries of Central Asia (Table 4). The total value of turnover in those directions, however, is low. Nevertheless, the presence of Polish goods in this part of Asia can constitute an additional rationale for the implementation of regular railway connections, partially supplementing the transport deficit on the New Eurasian Land Bridge towards the east.

With regard to the use of the New Eurasian Land Bridge in trade relations with the countries of Central Asia, China is the main importer of goods, with a growing turnover value (Fig. 3). The difference between the value of imports calculated by country of 


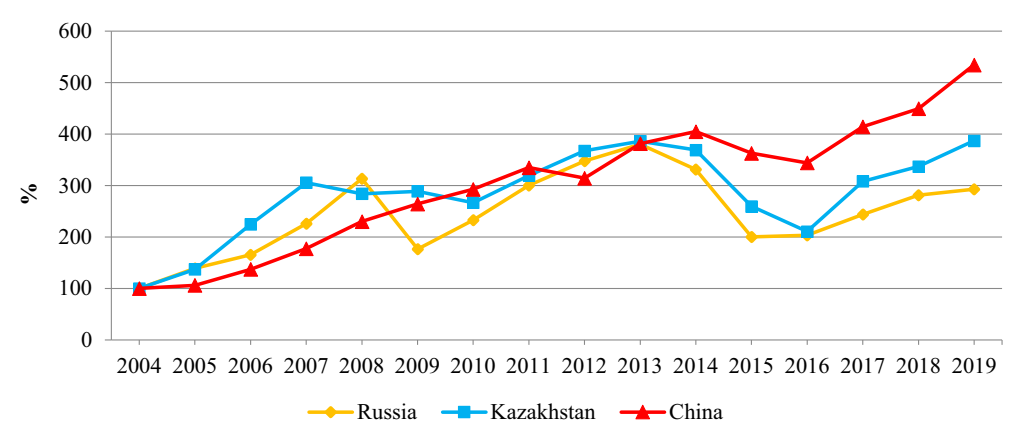

Fig. 4 Dynamics of export from Poland to countries on the route of the New Eurasian Land Bridge Economic Corridor $(2004=100 \%)$. Own elaboration based on Statistics Poland 2020

origin and by country of consignment is also noteworthy, as it suggests that the goods in question are transported through other countries. In the case of imports from China to Poland, 21 billion USD worth of goods is brought into the country directly (by different modes of transport, including rail). The remaining products (with a value of approximately 11.5 billion USD) are loaded in other countries, and it is likely that marine ports (or, alternatively, air cargo) in Western Europe (Hamburg, Rotterdam) and logistics facilities in Russia are used to effectuate this. Similarly, in the case of Kazakhstan, a large portion of goods is not transported directly.

Any analysis of the transport potential of the New Eurasian Land Bridge must consider the high value of goods exchanged between Poland and Russia (irrespective of the current limitations resulting from the ongoing embargo imposed on food products). Poland exports goods with a value of more than 8.3 billion USD to Russia (as of 2019). The value is more than twice as high as that of Poland's exports to China and all the countries of Central Asia combined. Excluding the import of energy engineering resources, the balance of Polish commercial exchange with Russia is positive. The spatial distribution of target points of Polish export to Russia, however, is not known, including the potential contribution of Asian destinations.

High competitiveness of import carried out by the ports in Hamburg and Rotterdam is a key threat to the further development and use of the New Eurasian Land Bridge by Poland. The threat also has the potential to affect the operations of the Deepwater Container Terminal in Gdańsk, which facilitates sea connections from the Far East. On

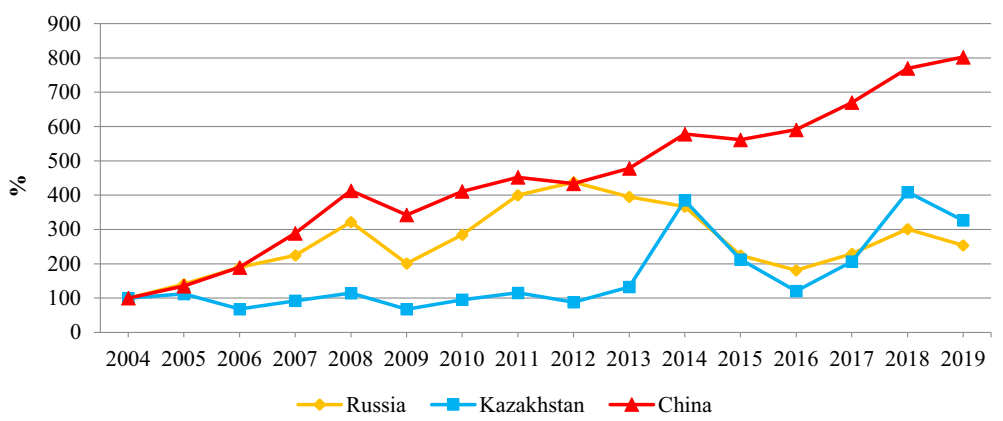

Fig. 5 Dynamics of import to Poland from countries on the route of the New Eurasian Land Bridge Economic Corridor, by country of origin of goods $(2004=100 \%)$. Own elaboration based on Statistics Poland 2020 


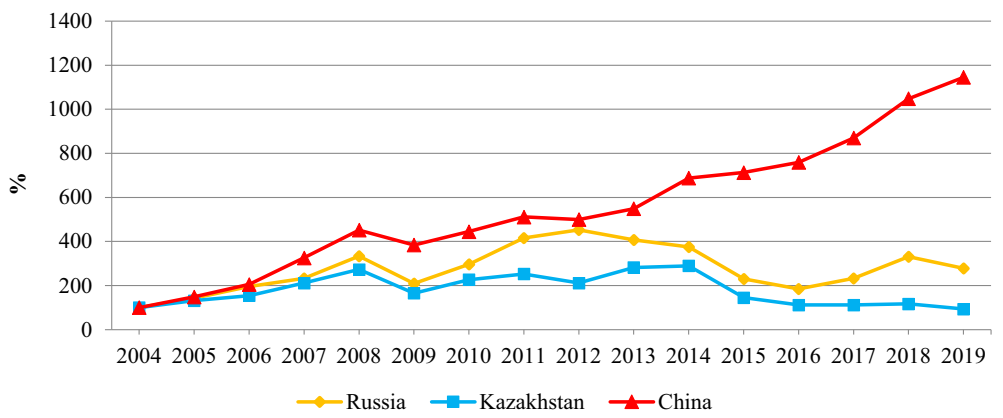

Fig. 6 Dynamics of import to Poland from countries on the route of the New Eurasian Land Bridge Economic Corridor, by country of consignment of goods $(2004=100 \%)$. Own elaboration based on Statistics Poland 2020

the other hand, the New Eurasian Land Bridge has the potential to develop further thanks to the relatively high export activity of Polish companies in markets like Russia, Kazakhstan, Uzbekistan, other countries of Central Asia, and Mongolia.

Direct import of goods to Poland from China as the country of consignment amounted to only $45.4-64.8 \%$ of the value of all goods produced in that country and transported to Poland in the 2004-2019 period. Germany's contribution as the intermediary in Poland's trade with China in the same period was the most significant, ranging from 13.3 to $27.3 \%$ (Fig. 3). From 2011, however, one can observe a decreasing tendency in this contribution, with a simultaneous increase in the value of direct import. These trends coincide with the timing of the launch of the first rail connections from Chongqing to Poland. The strongly positive dynamics of import in the following years also correspond with the increased volume of rail transport on the New Eurasian Land Bridge. It is not possible to determine to what degree such positive changes are related to investments in the container port in Gdańsk. However, the collected data indirectly suggest that the modal changes and increasing use of direct connections were responsible for these positive dynamics. According to historical data from 1997, 88\% of contemporary export from Poland to China was performed by sea (copper ore), whereas in import, 53\% of all goods were shipped to Poland through Germany via the Berlin-Warsaw corridor (Komornicki 2000). At the time, trade flows
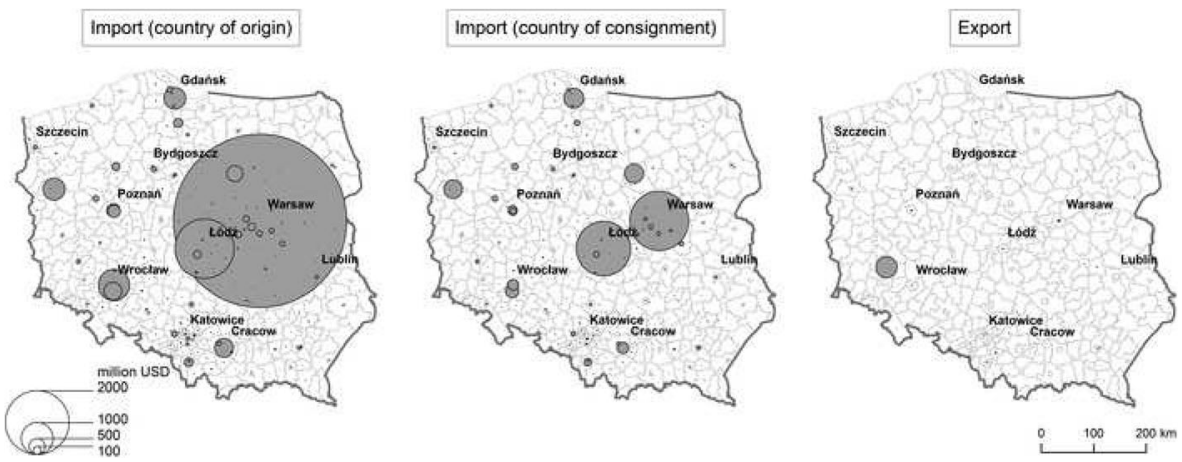

Fig. 7 Spatial variability of foreign trade between Poland and China on the powiat (county) level in 2015. Own elaboration based on Statistics Poland 2020 
through the eastern border did not exceed $1 \%$ of the total. In the same period, more than $90 \%$ of export to Kazakhstan and other countries of Central Asia was concentrated on the Polish-Belarusian border.

The existing changes in the value of trade turnover to and from the east in the years 2004-2019 are also worth a closer examination. During the economic crisis (2008), export to Russia broke down, but trade flows to China and Kazakhstan remained stable. This is confirmed by data from earlier analyses (Komornicki et al. 2015), according to which the crisis forced exporters to search for new non-European outlet markets. In the following years, the dynamics of export from Poland to Russia, China, and Kazakhstan were considerable until 2013. After that, the export value decreased, particularly to Russia and Kazakhstan (due to the Ukrainian crisis). Export to China also started decreasing until it reversed course in 2017 (Fig. 4). Assessments of these trends should consider that copper comprises a large portion of Polish export to China; thus, to a certain degree, the value of turnover is determined by the price of this raw material.

In terms of changes in the value of imports in the same period, we observe a breakdown in the years 2008-2009 on all connections analysed here, followed by a decrease in import from Russia and Kazakhstan from 2012 (i.e. before the Ukrainian crisis). At the same time, import from China continuously increased, particularly in terms of where goods were loaded (dispatched) (Figs. 5 and 6).

In Poland, on the local level (including counties), trade with China mostly concerns large urban agglomerations, with a predominance of import over export (Fig. 7). In the country-of-consignment analysis, manifestations of the use of the New Eurasian Land Bridge Economic Corridor in the transport of goods to Poland include the spatial distribution of import. Large cities such as Warsaw and Łódź stand out, as do two other centres in the vicinity of container terminals: Gorzów Wielkopolski in Western Poland (GVT Intermodal terminal in Rzepin) and Mława between Warsaw and Gdańsk (PKP Cargo terminal). It should be emphasised that part of the import occurring at those locations can also be conducted and processed by the DCT port in Gdańsk, omitting the New Eurasian Land Bridge entirely. The differences between import by country of origin and import by country of consignment suggest that the most important centre to which Chinese goods are delivered from third countries is Warsaw, followed by Wrocław and Kraków. These cities can be viewed as collection points for air cargo transport. Export to China is primarily concentrated in the copper basin of southwestern Poland and conducted from several largest cities. Its distribution, however, does not determine the course of the New Eurasian Land Bridge to any degree. The concentration of trade near railway line E 20 confirms the importance of the central transport corridor as the main axis of the SREB in Poland. Potential primary branches include rail routes from Warsaw through Mława to Gdańsk, and from Poznań to Wrocław.

\section{Conclusions}

The Silk Road Economic Belt is often presented as a great opportunity for development in Poland due to the development of Polish-Chinese political and economic contacts on the highest level, as well as a surge in interest on the part of local self-governing bodies and entrepreneurs. At first glance, the vision 
of Poland as a European hub seems attractive and feasible. In purely geographical terms, Poland is a natural gateway to European Union for the New Eurasian Land Bridge Economic Corridor-it is the first country on the route with access to the TEN-T network. Due to the unstable situation in Eastern Ukraine and unregulated relations with Iran, the transport route running through Belarus and Poland is currently not only the fastest but also the safest one. According to current studies concerning the Silk Road Economic Belt's chances for development (van der Putten et al. 2016; Pantucci and Lain 2016; Jakóbowski et al. 2018), competition for the location of hubs and operation of transit in Europe is particularly vigorous among countries vying for influence along the New Eurasian Land Bridge (running through Belarus and Poland) and the southern corridor (running through the Balkans). This analysis partially defies this thesis. The distribution of countries maintaining trade relations with China in the European Union seems to prefer the first of these two options. Moreover, both directions can function simultaneously and be complementary (reaching Germany, the Netherlands, France, and Spain via Poland, and Greece, Croatia, Bulgaria, Romania, and even Hungary via the southern route). If the southern branch includes a variant that omits the territory of Russia (e.g. variants that entail navigation on the Black and Caspian Seas via Turkey, Georgia, and Azerbaijan, or the Iranian variant), the existence of two or three complementary corridors can guarantee deliveries in even in light of rising cargo volumes and conditions of political instability.

In the context of the current intensity of railway traffic on the China-EU route, Poland has sufficiently developed linear and point infrastructure - particularly container terminals - to continuously operate transport flows. From Poland's standpoint, a large portion of connections between China and the European Union are transit connections, which have an insignificant impact on the economic development of the country while simultaneously contributing to the decapitalisation of infrastructure. Large infrastructure investments planned by 2030 can increase the capacity of the current network, freeing additional capacities that would enable Poland to increase cargo traffic from Asia. Moreover, the country may have an opportunity to integrate the region of Central and Eastern Europe with Scandinavia, increasing the accessibility for the New Eurasian Land Bridge for the latter region. Marine transport, however, remains competitive in terms of cost, and the volume of transport on those routes is incomparably higher. As a result, the developed land corridor can only serve as a complementary mechanism for the default sea route.

In the trade balance of Poland and China, import is increasingly prevalent (at a level of approximately 11:1), whereas around $35 \%$ of all goods are not brought to Poland directly from China. Poland can only fill container trains on the entire eastward route to a limited degree. Therefore, it would be important to consider streams of export from Poland to different regions of Russia, as well as to Central Asia (positive trade balance). The development of relations with Kazakhstan in particular offers a chance to leverage the SREB in the eastern direction.

However, higher demand for shipping along the New Eurasian Land Bridge Economic Corridor does not automatically mean that Poland will become the main hub on its European end. This study revealed the existence of other dimensions of competition beyond the route of the corridor itself. These include: 
- the modal dimension (rail transport versus marine transport in the context of emerging container ports on the Baltic Sea, and rail transport versus aviation transport in the context of plans to construct the Central Airport between Warsaw and Łódź);

- the modal dimension in the context of "the Belt" (rail transport versus road transport, which is already overtaking cargo in Eastern Europe);

- geographic location on the east-west axis (competition between logistics centres and terminals in Russia, Belarus, Baltic states, Poland, and Germany).

In this situation, factors that potentially favour the creation of a Silk Road Economic Belt hub in Poland include:

- the multilateral character of the corridor (operation of trade flows not only from China to Europe but also from China to Russia and the countries of Central Asia);

- activation of terminals serving as reloading stations at Poland's eastern border (in such a way as to enable reloading directly from 1520-mm infrastructure);

- development and building of new terminals near the western border of Poland that could directly support the dispersed German market (in road transport);

- integration of SREB land corridor terminals and Baltic terminals, and incorporation of the Swedish direction;

- intensification of trade exchange between Poland (as well as other countries of Central and Eastern Europe) and China, particularly in terms of export.

Based on the available evidence, we believe that Poland is likely to adopt the role of a regional hub in Central and Eastern Europe, though limited to the region's southern territories (the Czech Republic, Slovakia, Hungary), without the Baltic states, which have their own connections with the New Eurasian Land Bridge through the territory of Russia. The Scandinavian direction also offers some potential due to the important role of Sweden in trade between the EU and China. An important component contributing to the competitive advantage of Poland is its rapidly expanding network of motorways and express roads. However, in the context of establishing a Silk Road Economic Belt hub, it can either constitute an opportunity (distribution of streams from terminals while maximising the contribution of rail transport) or a threat (use by terminals located abroad, with disproportionate involvement of environmentally unfriendly road transport).

To sum up, some hopes and expectations observed in Poland related to the planned implementation of the Silk Road Economic Belt are only partially reflected in reality. The advantage of Poland's geographic location can favour an excessive orientation of the economy toward transit rather than framing the country as a destination or point of origin in itself (Komornicki et al. 2006). Infrastructure investments in Central and Eastern Europe (particularly in the countries of the European Union) should prioritise the economic relations of those countries rather than focus on operating traffic between China and the economic core of Western Europe.

Funding information This study was financed from the funds for ongoing research of the Department of Earth Sciences and Spatial Management, Maria Curie-Skłodowska University, and Faculty of Economics, Maria Curie-Skłodowska University. The study also presents the results of the research project "Economic, 
social, and geopolitical factors influencing border traffic: Foundations for modelling and forecasting on the example of Poland (BORDER-TRAF)" financed by the National Science Centre (Poland) on the basis of decision no. DEC-2016/21/B/HS4/03019.

\section{Compliance with ethical standards}

Conflict of interest The authors declare that they have no conflict of interest.

Research involving human participants and/or animals This article does not contain any studies with human participants or animals performed by any of the authors.

Informed consent For this type of study, formal consent is not required.

Open Access This article is licensed under a Creative Commons Attribution 4.0 International License, which permits use, sharing, adaptation, distribution and reproduction in any medium or format, as long as you give appropriate credit to the original author(s) and the source, provide a link to the Creative Commons licence, and indicate if changes were made. The images or other third party material in this article are included in the article's Creative Commons licence, unless indicated otherwise in a credit line to the material. If material is not included in the article's Creative Commons licence and your intended use is not permitted by statutory regulation or exceeds the permitted use, you will need to obtain permission directly from the copyright holder. To view a copy of this licence, visit http://creativecommons.org/licenses/by/4.0/.

\section{References}

Aoyama R (2016) One Belt, One Road': China's new global strategy. J of Contemp East Asia Stud 5(2):3-22. https://doi.org/10.1080/24761028.2016.11869094

Atlas Zheleznykh Dorog Rossii (2015). Feoriia, Institut Ekonomiki i Razvitiia Transporta, Moskva

Atlas Zheleznykh Dorog Stran OSZhD: Illyustrirovannaya kartograficheskaya enciklopediya (2013). ZAO Associirovannyj Kartograficzeskij Centr-M, Moskva

Bachulska A (2017) Polska. In: Iwanek K, Pietrewicz O (eds) Chiński projekt „Nowego Jedwabnego Szlaku”. Retoryka a rzeczywistość. Akademia Sztuki Wojennej, Warszawa. http://www.cbb.akademia.mil.pl/g2 /oryginal/2017_08/raport-chinski-projekt-njs.pdf. Accessed 21 August 2018, pp 165-180

Bartosiewicz A, Szterlik P (2019) Łódź's benefits from the One Belt One Road initiative. Int J of Logistics Res and Applications 22(1):47-63. https://doi.org/10.1080/13675567.2018.1526261

Beeson M (2018) Geoeconomics with Chinese characteristics: the BRI and China's evolving grand strategy. Econ and Political Stud 6(3):240-256. https://doi.org/10.1080/20954816.2018.1498988

Beijing Trans Eurasia International Logistics (2020). http://en.trans-eurasia.cn. Accessed 6 March 2020

Belarusian Railway (2018). http://www.rw.by/en/freight/container_transportation. Accessed 13 November 2018

Belintertrans (2018). http://www.belint.by/en/services/train. Accessed 13 November 2018

Bulis A, Skapars R (2014) Development of "New Silk Road" Northern branch through seaport of Riga in Latvia. Procedia - Soc and Behav Sci 150:1222-1229. https://doi.org/10.1016/j.sbspro.2014.09.138

Bykadorov SA (2017) About transport costs calculation on the Transsiberial railway. Sci J of Marit Res 31(1): 38-44. https://doi.org/10.31217/p.31.1.7

Casarini N (2016) When all roads lead to Beijing. Assessing China's New Silk Road and its implications for Europe. The Int Spectator 51(4):95-108. https://doi.org/10.1080/03932729.2016.1224491

Chubarov I (2018) Challenges and opportunities for the spatial development of Eurasia under the BRI: the case of the Eurasian Economic Union. Area Dev and Policy 4(1):81-97. https://doi.org/10.1080 /23792949.2018.1527181

Ciemnoczułowski T (2009) Szerokim torem LHS. Księży Młyn, Łódź

Clarke M (2018) The Belt and Road Initiative: exploring Beijing's motivations and challenges for its New Silk Road. Strateg Anal 42(2):84-102. https://doi.org/10.1080/09700161.2018.1439326

Debreczeni G (2016) The New Eurasian Land Bridge: opportunities for China, Europe, and Central Asia. The Public Sphere J 4(1):39-54 
Development Plan of China-Europe Freight Train Construction (2016-20) (2018). The Leading Group Office on the Construction of the Belt and Road. https://eng.yidaiyilu.gov.cn/zchj/qwfb/35975.htm. Accessed 6 December 2018

DHL Global Forwarding (2020). https://www.logistics.dhl/content/dam/dhl/global/dhl-globalforwarding/documents/pdf/dhl-glo-dgf-rail-freight.pdf. Accessed 6 March 2020

Diener AC (2015) Parsing mobilities in Central Eurasia: border management and New Silk Roads. Eurasian Geogr and Econ 56(4):376-404. https://doi.org/10.1080/15387216.2015.1078736

European Commission (2013) Trans-European Transport Network (TEN-T). https://ec.europa. eu/transport/themes/infrastructure/ten-t_en. Accessed 26 March 2020

European Commission (2016) Elements for a New UE Strategy on China. JOIN(2016) 30 final (22.06.2016). $\mathrm{http} / /$ eeas.europa.eu/archives/docs/china/docs/joint communication to the european parliament and the_council__elements_for_a_new_eu_strategy_on_china.pdf. Accessed 12 September 2018

Eurostat Database (2020). http://www.ec.europa.eu/eurostat/data/database. Accessed 11 March 2020

Fahrplanauskunft für Bahn \& Zugreisen mit Preisvergleich (2018). http://www.marcopolo. de/routenplaner/bahn.html. Accessed 3 January 2018

Fallon T (2015) The New Silk Road: Xi Jinping's Grand Strategy for Eurasia. American Foreign Policy Interests 37(3):140-147. https://doi.org/10.1080/10803920.2015.1056682

Gallo E (2014) Eurasian Union Versus Silk Road Economic Belt? Policy Brief No. 159. Institute For Security and Development Policy. https://www.files.ethz.ch/isn/184909/2014-gallo-eurasian-union-versus-silkroad-economic-belt.pdf. Accessed 12 December 2018

Go China (2018). http://www.gochina.gov.pl/strategia GoChina. Accessed 2 December 2018

Góralczyk B (2017) China's interests in Central and Eastern Europe: enter the dragon. Eur View 16:153-162. https://doi.org/10.1007/s12290-017-0427-9

Górski J (2017) Central and Eastern Europe, Group 16+1 and One Belt One Road: the case of 2016 SinoPolish Comprehensive Strategic Partnership. Transnatl Disput Manag 14(4)

Grzywacz A (2020) Closer to a threat than an opportunity: Polish perception of China's rise and international engagement. Asia Eur J 18:177-194. https://doi.org/10.1007/s10308-019-00541-7

Guluzian CR (2017) Making Inroads: China’s New Silk Road Initiative. Cato J 37(1)

GVT (2018). http://www.gvtintermodal.com/en. Accessed 30 November 2018

H\&T (2018). http://www.chinaeuroperailwayexpress.com/products. Accessed 14 December 2018

$\mathrm{He} \mathrm{H}$ (2016) Key challenges and countermeasures with railway accessibility along the Silk Road. Eng 2:288291. https://doi.org/10.1016/J.ENG.2016.03.017

Holslag J (2017) How China's New Silk Road threatens European trade. The Int Spectator 52(1):46-60. https://doi.org/10.1080/03932729.2017.1261517

Hu B, Liu Q, Yan J (2017) Promoting the Belt and Road Initiative by strenghtening '5+1' cooperation. In: Song L, Garnaut R, Fang C, Johnston L (eds) China's new sources of economic growth. ANU Press, Canberra, pp 409-429

Jakimów M (2019) Desecuritisation as a soft power strategy: the Belt and Road Initiative, European fragmentation and China's normative influence in Central-Eastern Europe. Asia Eur J 17(4):369-385. https://doi.org/10.1007/s10308-019-00561-3

Jakóbowski J, Kaczmarski M (2017) Nietrafiona oferta Pekinu: “16+1” a chińska polityka wobec Unii Europejskiej. Komentarze OSW 250. https:/www.osw.waw.pl/pl/publikacje/komentarze-osw/2017-0915/nietrafiona-oferta-pekinu-161-a-chinska-polityka-wobec-unii. Accessed 12 November 2018

Jakóbowski J, Popławski K, Kaczmarski M (2018) The Silk Railroad. The EU-China rail connections: background, actors, interests. Centre for Eastern Studies, Warsaw

Jakubowski A, Miszczuk A, Kawałko B, Komornicki T, Szul R (2017) The EU’s New Borderland: crossborder relations and regional development. Routledge, London-New York

Kaczmarski M (2017) Two ways of Influence-building: the Eurasian Economic Union and the One Belt, One Road Initiative. Eur-Asia Stud 69(7):1027-1046. https://doi.org/10.1080/09668136.2017.1373270

Kaliszuk E (2016) Chinese and South Korean investment in Poland: a comparative study. Transnatl Corp Rev 8(1):60-78. https://doi.org/10.1080/19186444.2016.1162483

Kamel MS (2018) China's Belt and Road Initiative: implications for the Middle East. Camb Rev of Int Aff 31(1):76-95. https://doi.org/10.1080/09557571.2018.1480592

Kavalski E (2019) China in Central and Eastern Europe: the unintended effects of identity narratives. Asia Eur J 17(4):403-419. https://doi.org/10.1007/s10308-019-00563-1

Khan S, Liu G (2018) The China-Pakistan Economic Corridor (CPEC): challenges and prospects. Area Dev and Policy 4(4):466-473. https://doi.org/10.1080/23792949.2018.1534549

Komornicki T (2000) Potoki towarowe polskiego handlu zagranicznego a międzynarodowe powiązania transportowe. Prace Geogr. 177. IGiPZ PAN, Warszawa 
Komornicki T (2008) Granica polsko-białoruska jako bariera przestrzenna. In: Świątek D, Bednarek M, Siłka M Współczesne problemy badawcze geografii polskiej - geografia człowieka. Dokumentacja Geogr. 36:55-61

Komornicki T (2019) Transport infrastructure and accessibility. In: Gorzelak G (ed) Social and economic development in Central and Eastern Europe: stability and change after 1990. Routledgde, London, pp 244-266

Komornicki T, Śleszyński P, Węcławowicz G (2006) O potrzebie nowej wizji rozwoju infrastruktury transportowej Polski. Przegląd Komunikacyjny 45(6):13-20

Komornicki T, Zaucha J, Szejgiec B, Wiśniewski R (2015) Powiązania eksportowe gospodarki lokalnej w warunkach zmiennej koniunktury - analiza przestrzenna. Prace Geogr 250. IGiPZ PAN, Warszawa

Kowalski B. (2017) China's foreign policy towards Central and Eastern Europe: the '16+1' format in the South-South cooperation perspective. Cases of the Czech Republic and Hungary. Camb J of Eurasian Stud 1(1). https://doi.org/10.22261/7R65ZH

Kratz A (2016) The best of both worlds? CEE's place in China-Europe economic relations. In: China's investment in influence: the future of 16+1 cooperation, ECFR/199:6-9. http://www.ecfr.eu/page//China_Analysis_Sixteen_Plus_One.pdf. Accessed 10 October 2018

Liu W, Dunford M (2016) Inclusive globalization: unpacking China's Belt and Road Initiative. Area Dev and Policy 1(3):323-340. https://doi.org/10.1080/23792949.2016.1232598

Liu HY, Tang YK, Chen XL, Poznanska J (2017) The determinants of Chinese outward FDI in countries along 'One Belt One Road. Emerg Mark Finance and Trade 53(6):1374-1387. https://doi.org/10.1080/1540496 X.2017.1295843

Liu W, Dunford M, Gao B (2018) A discursive construction of the Belt and Road Initiative: from neo-liberal to inclusive globalization. J of Geogr Sci 28(9):1199-1214. https://doi.org/10.1007 /s11442-018-1520-y

Lubina M (2017) From Geopolitical chance to security threat: Polish public political discourse on the One Belt One Road Initiative. Pol Political Sci Yearb 1(46):221-238. https://doi.org/10.15804/ppsy2017114

Majman S (2015) Silk Road on the Central and Eastern Europe Angle. http:/en.drc.gov.cn/SlawomirMajman. pdf. Accessed 11 October 2018

Minghao Z (2016) The Belt and Road Initiative and its implications for China-Europe relations. The Int Spectator 51(4):109-118. https://doi.org/10.1080/03932729.2016.1235819

Ministry of Commerce of People's Republic of China (2015) Qian Keming: Chinese foreign trade is benefiting the countries along the line of the Belt and Road. http://english.mofcom.gov. cn/article/newsrelease/significantnews/201509/20150901122353.shtml . Accessed 2 November 2018

Ministry of Development of Poland (2018). https://www.mr.gov.pl/media/25197/Lista_umow_wizyta_CHRL. pdf. Accessed 30 January 2018

Ministry of Investments and Development (2017) Strategia na Rzecz Odpowiedzialnego Rozwoju do roku 2020 (z perspektywą do 2030 r.). https://www.miir.gov.pl/media/48672/SOR.pdf. Accessed 30 January 2018

Misiagiewicz J, Misiagiewicz M (2016) China's 'One Belt, One Road' Initiative - the perspective of the European Union. Annales Universitatis Mariae Curie-Skłodowska. Sectio K 23(1):33-42. https://doi. org/10.17951/k.2016.23.1.33

National Development and Reform Commission (2015) Vision and actions on jointly building Silk Road Economic Belt and 21st-Century Maritime Silk Road', 2015/03/28. http://en.ndrc.gov. cn/newsrelease/201503/t20150330_669367.html. Accessed 1 October 2018

OOCL (2018). http://www.oocl.com/eng/ourservices/vessels. Accessed 8 December 2018

Pantucci R, Lain S (2016) I. China's grand strategy: the Belt and Road Initiative. Whitehall Pap 88(1):7-16. https://doi.org/10.1080/02681307.2016.1274604

Pendrakowska P (2018) Poland's perspective on the Belt and Road Initiative. J of Contem East Asia Stud 7(2): 190-206. https://doi.org/10.1080/24761028.2018.1552491

PKP LHS (2018). https://hs.com.pl/pl/wydarzenia/aktualnosci/2018/427. Accessed 2 December 2018

PKP LHS (2020). https://hs.com.pl/pl/wydarzenia/aktualnosci/2020/486. Accessed 6 March 2020

PKP PLK (2005) Annual Report 2005. PKP PLK, Warsaw

PKP PLK (2018) Annual Report 2018. PKP PLK, Warsaw

Ploberger C (2017) One Belt, One Road - China's new grand strategy. Journal of Chinese Economic and Business Studies 15(3):289-305. https://doi.org/10.1080/14765284.2017.1346922

PM of Poland (2018) Prime Minister Beata Szydło at the international Belt and Road Forum. https://www. premier.gov.pl/mobile/en/news/news/prime-minister-beata-szydlo-at-the-international-belt-and-roadforum.html . Accessed 30 December 2018

Polish Investment \& Trade Agency (2017) Belt and Road Forum: Poland with plans to become European transport hub. http://www.paih.gov.pl/20170515/belt_and_road_forum2017. Accessed 1 December 2018 
Rodemann H, Templar S (2014) The enablers and inhibitors of intermodal rail freight between Asia and Europe. J Rail Transp Plan Manag 4(3):70-86. https://doi.org/10.1016/j.jrtpm.2014.10.001

Rodrigue JP, Comtois C, Slack B (2017) The Trans-Asian Railway (Eurasian Landbridge). In: Rodrigue JP, Comtois C, Slack B (eds) The geography of transport systems. Routledge, New York, pp 207-247

Rosik P, Komornicki T, Goliszek S, Duma P (2018) Improvement of accessibiliy in Eastern Europe due to implementation of road projects in the Via Carpatia corridor. Mitt Österr Geogr Ges 160:177-196. https://doi.org/10.1553/moeg160s177

Seo YF, Chen F, Roh SY (2017) Multimodal transportation: the case of Laptop from Chongqing in China to Rotterdam in Europe. The Asian J of Shipp and Logist 33(3):155-165. https://doi.org/10.1016/j. ajs1.2017.09.005

Silin Y, Kapustina L, Trevisan I, Drevalev A (2018) The silk road economic belt: balance of interests. Econ and Political Stud 6(3):293-318. https://doi.org/10.1080/20954816.2018.1499072

Skorupska A, Szczudlik-Tatar J (2014) Regional cooperation key to Polish-Chinese strategic partnership. PISM Strateg File 25(61). https://www.pism.pl/files/?id_plik=18741. Accessed 19 October 2018

Song W (2019) Logic of the Chinese developmental state and China's geo-economic engagement with Central and Eastern Europe. Asia Eur J 17(4):387-401. https://doi.org/10.1007/s10308-019-00562-2

Stankiewicz R, Stiasny M (2014) Atlas linii kolejowych Polski. Eurosprinter, Rybnik

Stanzel A (2016) Introduction. In: China's investment in influence: the future of $16+1$ cooperation, ECFR/199:10-12. http://www.ecfr.eu/page/-/China_Analysis_Sixteen_Plus_One.pdf. Accessed 7 November 2018

Statistics Poland (2020) Foreign Trade. http://swaid.stat.gov.pl/EN/SitePagesDBW/HandelZagraniczny.aspx. Accessed 26 March 2020

Suleymanov E (2017) Significance and prospect of BTK (Baku-Tbilisi-Kars) railway construction for Eurasian distribution industry. https://euracouncil.org/. Accessed 10.03.2020

Summers T (2016) China's 'New Silk Roads': sub-national regions and networks of global political economy. Third World Q 37(9):1628-1643. https://doi.org/10.1080/01436597.2016.1153415

Szczudlik J (2016a) Poland on the Silk Road in Central Europe: to become a hub of hubs? In: Putten van der FP, Seaman J, Huotari M, Ekman A, Otero-Iglesias M (eds) Europe and China's New Silk Roads. ETNC Report December 2016. https://www.ifri.org/en/publications/ouvrages-de-lifri/europe-and-chinas-newsilk-roads. Accessed 10 October 2018

Szczudlik J (2016b) When the Silk Road meets the EU: towards a new era of Poland-China relations? In: China's investment in influence: the future of 16+1 cooperation. ECFR/199. https://www.ecfr.eu/page//China_Analysis_Sixteen_Plus_One.pdf. Accessed 15 November 2018

Szczudlik-Tatar J (2015) Poland-China strategic partnership: waiting for more results. PISM Bull 106(838). http://www.pism.pl/files/?id_plik=20936. Accessed 16 November 2018

Tarkhov S (2018) Network development of the world's high-speed railways. EUR XXI 34:95-112. https://doi. org/10.7163/Eu21.2018.34.6

Tekdal V (2018) China's Belt and Road Initiative: at the crossroads of challenges and ambitions. The Pac Rev 31(3):373-390. https://doi.org/10.1080/09512748.2017.1391864

UTK (2018). http:/www.utk.gov.pl/pl/dostep-do-infrastruktur/dostep-do-infrastruktur/mapa-obiektowinfrastru/terminale-intermodalne. Accessed 15 January 2018

van der Putten, FP, Seaman J, Huotari M, Ekman A, Otero-Iglesias M (2016) The EU Level: 'Belt and Road' Initiative Slowly Coming to Terms with the EU Rules-based Approach. In: Putten van der FP, Seaman J, Huotari M, Ekman A, \& Otero-Iglesias M (eds) Europe and China's New Silk Roads, ETNC Report December 2016. https://www.ifri.org/en/publications/ouvrages-de-lifri/europe-and-chinas-new-silk-roads. Accessed 10 October 2018

Vangeli A, Pavlićević D (2019) Introduction: new perspectives on China - Central and Eastern Europe relations. Asia Eur J 17(4):361-368. https://doi.org/10.1007/s10308-019-00560-4

Wang Y (2015) China's 'New Silk Road': a case study in EU-China relations. In: Amighini A, Berkofsky A (eds) Xi's policy gambles: the bumpy road ahead. Italian Institute for International Political Studies, Milan, pp 93-109

Wang J, Jiao J, Ma L (2018) An organizational model and border port hinterlands for the China-Europe Railway Express. J of Geogr Sci 28:1275-1287. https://doi.org/10.1007/s11442-018-1525-6

Wilson JL (2016) The Eurasian Economic Union and China's silk road: implications for the Russian-Chinese relationship. Eur Politics and Soc 17(1):113-132. https://doi.org/10.1080/23745118.2016.1171288

Wuhan Asia-Europe Logistics (2020). http://www.wae-logistics.com. Accessed at: 6 March 2020 
Xinhuanet (2018) China's Yiwu sends first freight train to Prague. http://news.xinhuanet.com/english/2017-09 /09/c_136597151_2.htm. Accessed 18 January 2018

Ye M (2015) China and competing cooperation in Asia-Pacific: TPP, RCEP, and the New Silk Road. Asian Secur 11(3):206-224. https://doi.org/10.1080/14799855.2015.1109509

Zasiadko M (2018) PKP has launched a new route to China. https://www.railfreight.com/beltandroad/2018/06 /28/pkp-has-launched-a-new-route-to-china/. Accessed 18 December 2018

Zhongguo Tielu Dituji (2015). China Railway Publishing House, Beijing

Publisher's note Springer Nature remains neutral with regard to jurisdictional claims in published maps and institutional affiliations. 